\title{
The Relationship between Intensity Usage of Social Media with Women's Small Online Business Happiness
}

\author{
Rini Sudarmanti \\ \{rini.sudarmanti@paramadina.ac.id\} \\ Universitas Paramadina, Indonesia
}

\begin{abstract}
The differences in stereotypes between women and men appear in their daily communication activities while using social media. This assumption might also apply for Indonesian women who choose social media as their medium for developing their business online. This study aims to determine the relationship between the use of social media with the happiness of businesswomen. We focus on those who use Facebook/Instagram as theirs marketing online media. The survey method is used by distributing questionnaires through snowball sampling technique to women who own online business. The results showed that the relationship between the usage intensity of social media provides a feeling of happiness for businesswomen on certain level. Further studies are needed to explore the use of social media so that it can be maximally utilized to increase the capacity of women.
\end{abstract}

Keywords: Intensity, Social Media, Women's Happiness, Business Online.

\section{Introduction}

The economic crisis in East Asia raised first in Thailand in July 1997. This situation also happened in Southeast Asia countries such as Malaysia, Philippines, Indonesia, South Korea, and Hong Kong, China, Taiwan, and also Japan [1][2]. Women play an important role in developing economic level while facing crisis attack. Women become entrepreneurs in to overcome economic impact problems in their families. some parts of Indonesia.

In 2012, The Indonesian Business Women's Association (IWAPI) [3] noticed that approximately about 40,000 small-medium enterprises owned by Indonesia women. The Ministry of Cooperatives and Small and Medium Enterprises also noted that in 2018 the number of entrepreneurs reached nearly 60 million. Of these, more than 14 million businesses were managed by women. The contribution of these business to Gross Domestic Product (GDP) level has reached $9.17 \%$. Their contributions to exports also reached more than 5\% [4].

Almost women in the world exposed their contribution to maintain economic problems within society. This such kind of condition similarly also happened in Canada, German, Australia, United States of Amerika [5]. The small and medium enterprises which run by women play an important role in the country's economic progress. These achievements have proofed that women are not a kind of burden in the society. Their role are potentials and need to be considered as well as need to be keep encouraged and developed.

Meanwhile, internet users in Indonesia are increasing in number. They are growing rapidly. The results of a survey conducted by the Indonesian Internet Service Providers Association or APJII (2018) [6], noted that currently $64.8 \%$ of the total population of Indonesia or around 171.17 million people out of 264,16 million are exposed to the internet. This number increased 
from the previous year in 2017 where the number of internet users was around $54.68 \%$ of the total population of Indonesia.

The development of internet penetration has made a variety of daily activities that used to be manual or using conventional equipment, then switching to utilize digital devices. Not only concerning information media, in the field of marketing goods and services, the internet is also very helpful in increasing sales promotion and bringing it closer to consumers.

The internet also makes women have wider opportunities to participate in public spaces. For them it is better to work at home to take care of the home and family rather than working in the office. They do not need to leave their home while working. Through social media, women can easily connect and communicate with consumers without having to meet face to face.

This study aims to explore whether there is a link between the intensity of using internetbased social media as a marketing medium business online owned by women and their happiness. The results of this discussion are expected to provide alternative ideas to consider the access index of using internet-based communication media as one that determines the quality of women's lives.

\section{Literature Review}

Wood [7] defined, communication is a dynamic, systemic process in which two levels of meaning are created and reflected in human interaction with symbols. Communication is a dynamic process, a systemic process that involves two levels of meaning. This meaning is the result of construction. It derives from the process of reflection of interactions between people who use symbols that are the result of their creation. Based on this opinion, it can be understood simply that the communication process is essentially a depiction of everyday human life which involves the use of symbols as a result of human thought.

According to uses and gratification assumption, people do selection while using media. [8] The use of media derives from rewards that you expect from using internet media, you can choose any information or news that you need. The development of technology, such as internetbased media encourages people to use the internet in their daily lives. The use of internet media as communication media is a dynamic and systemic process that reflects their creative lives to exchange symbols. People will make decisions about which content they choose based on their expectations.

\subsection{New Media and Social Media}

In the current era, the presence of social media such as vlogs, Instagram Facebook to Twitter are the main needs for people's lives. Currently social media is making a fair large community dependency. Social media makes it easy for everyone to be able to communicate, participate, share and form a network online so that they can disseminate the content they create themselves [9].

Terry Flew in Ardianto [10] said that, "as those forms that combine the three CS: computing and information technology (IT); communication network; digitized media \& information content." New media is a new form of a combination of computerization and information technology, across communication networks, through digital media, and information content. New media is a collaboration of technology and media content engaged in the social communication network 


\subsection{Media Usage Intesity}

The utilization of internet-based communication media is can be considered as a reflection of the quality of human life both for men and women. They interaction is using message symbols by utilizing the internet to produce changes in social life and even culture.

Our society considered and admitted that internet-based communication media to make their lives much better. They use the internet to communicate and socialize through the media, such as to find information or jobs. Besides, they use the internet to facilitate other activities such as payment (internet banking), looking for additional information, food recipes, and so on so that almost all needs can be more easily and practically.

Usage intensity of internet-based media is not only related to the frequency and intensity of its use as the media in general. Social media can connect and animate friendships and encourage self-disclosure [11]. The intensity of the use of Facebook can encourage the establishment of friendship communication and even social capital [12]. The intensity of the use of social media may also differ from one another. Wang [13] concluded that the use of Twitter as one of social media depends on the level of openness that is influenced by cultural background.

\subsection{Media Usage Intensity}

Gender Mainstreaming is one of the aspects that becomes the policy direction and priority strategy of the development movement. The success of this mainstreaming step can be seen from the Human Development Index (HDI) which covers 3 (three) dimensions, namely health, education and a decent standard of living.

From the HDI score values can be obtained Gender Development Index (IPG) which compares the HDI ratio of women and men. IPG score values can be used to find out more about the impact of development on the quality of the condition of women and men. The score of the Gender Empowerment Index (IDG) score is intended to determine the extent of involvement and participation of women's roles in the political and economic fields.

Indonesia in 2017, women's development is crawling faster than men's development achievements. This condition has increased the value of the Gender Development Index (IPG) to 0.14 points, an increase of 0.15 percent compared to 2016. Although Indonesia's IPG has increased, this achievement has not succeeded in boosting the score of the IPG score between 2010-2015. The 2017 IPG score is still below the 2015 achievement of 91.03 [14].

In the health sector, generally, women's age or women's life expectancy lasts longer than men's, although health complaints are more experienced by women than male. This condition does not occur as in the field of education where even though the opportunity for education is the same between men and women, still, men have greater opportunities in entering school for studies.

The gap between women and men also occurs in the economic field. The quality index of development achievements is dominated by men, expenditure per capita, men reach 14.93 million per year, while women only 8.75 million per year. share Women's is lower in various fields of employment. The female workforce is less than $10 \%$ and only fills in areas that are not more productive than men such as the service sector, provision of accommodation and trade. The opportunity to work in public space is wider open for men than women, especially in productive sectors such as mining and quarrying, electricity and gas procurement, information and communication, as well as real estate type housing. 
Until now, the aspects of education, health and economy are still to be kind of reference for measuring the quality of life in Indonesia. However, if it was explored further, quality of life is not enough to be measured by these three kind aspects. Quality of life concerning personal subjectivity [15]. Diener, Lucas \& Oishi [16] also noted that subjective well-being is "a person's cognitive and affective evaluation of his or her life". Well-being is very closely related to the meaning of cognitive and emotional response of life experiences.

While women's responses to their experiences using social media to do business by utilizing the internet, it can be reflected in the form of positive and negative communication actions. Positive action signifies a happy subjective experience. Likewise, if her experiences are something unpleasant, her negative subjective experience will be seen from her communication that illustrates of unhappiness.

Many scholars concern with the subjective experience which is reflected in the act of communication. They noted that both women and men have different communication actions. Both of them have their peculiarities while interaction. The assumption of this study is on the subjectivity of women's communication using internet-based social media with happy experiences. We assume that the experience of using social media for women is certainly different from men.

In the meantime, everybody's abstract experience is unquestionably unique, however the experience of being cheerful can be felt by everybody, in spite of the way that it originates from various social foundation, social class, financial level extraordinary. It is also happened while using social media. For example, the use of social media, such as Facebook can affect life satisfaction [17]. We simplified happy experiences as satisfaction or subjective well-being. The measurement of happiness in this study adopted from the measurement of subjective well-being used by the study of Ellison \& Steinfield [18]. Happiness is measured internet use and life satisfaction in general while using Social network Sites (SNS).

\section{Research Methods}

This research was conducted by survey method. Data was collected by distributing questionnaires to several women who owned online businesses. Then the next respondent is obtained by using the snowballing technique. The first respondent recommends to other respondents. The distribution taken only for a period of 2 (two) weeks. By that time, we are collecting as many as 46 questionnaires, unfortunately only 45 questionnaires that was eligible to be processed.

The questionnaire consisted 21 closes answered of two variables, dependent namely the intensity of social media use, which was measured by indicating the number of friends, and the time spent using social media (Facebook and or Instagram). The other variable was the independent variable of women's happiness, which was measured by indicating of the use of social media, kinship relationship such as greeting old and new friends, showing self-esteem, and satisfaction using the media for business purposes. Pearson's formula value was used for testing data correlation between those two variables data. 


\section{Finding and Discussion}

Data obtained by non-probability brings the consequence that the results obtained cannot be generalized. Nevertheless, the data is still processed by SPSS tool. Respondents are 45 women online business owners between 21-47 years old. Their average age is 33,3 years old. They offer a variety of business products, including fashion products, food, accessories, party supplies and so on. As many as 52.2\% have been in this online business for more than 24 months or 2 years. While the online media most often used for business is Instagram, then in the next sequence is Facebook, and thirdly joining e-commerce sites like Shopee, Tokopedia and so on.

The respondents have large amount of internet's friends. Most of respondents, as many as $65.2 \%$ have between 500-1 million people friends or followers. Only around $6.5 \%$ have more than 1 million friends or followers. They interact in the social media world for more than 5 hours a day $(50 \%)$.

Most of the respondents admit that social media Facebook or Instagram that they use it as part of their daily lives. But some of them treat social media as nothing more than media for business or just seeking material benefits. Whatever their intended to use, they all gave their consent to the statement of being able to master the various features available on Facebook and Instagram to support their business needs. There is no doubt among respondents regarding women's ability to mastery internet-based social media features.

The aim to build friendships remains excellent when respondents are asked about the benefits of using social media. As many as $71.7 \%$ of respondents prioritize friendship, primarily to establish friendships with whom are rarely met or located in different places. Besides, around $94 \%$ of respondents get potential buyers through social media.

Respondents also admitted that getting ideas and product inspiration through social media. They can exchange ideas and provide input to each other and then try according to their respective abilities. Involvement in online business makes them feel more alive than in real life where they often do not know what to do to fill in their free time.

Respondents also admitted that their involvement in online business made them feel better. They feel more respected for their existence and trained to be able to divide their time and concentration. More than $80 \%$ of respondents still try to be able to serve customers even though they are busy.

The results of research processing show that around $97.9 \%$ of respondent feel happy, prosperous, and able to develop themselves, build relationships and trust in each other. While the number of respondents who felt unhappy using social media as marketing media was only around $2.2 \%$. The number was very small and could be ignored.

Table 1. Correlation between variables

\begin{tabular}{|l|c|c|c|}
\hline \multirow{2}{*}{ Pearson Correlation } & & Total Y & Total X \\
\hline \multirow{2}{*}{ Sig. (1-tailed) } & Total Y & 1.000 & .605 \\
\cline { 2 - 4 } & Total X & .605 & 1.000 \\
\hline \multirow{2}{*}{$\mathrm{N}$} & Total Y &. & .000 \\
\cline { 2 - 4 } & Total X & .000 &. \\
\hline & Total Y & 45 & 45 \\
\cline { 2 - 4 } & Total X & 45 & 45 \\
\hline
\end{tabular}


Large correlation collected in the calculation of 0.605 with a significance level of 0.0000 . When referring to the interpretation table correlation this number shows a strong relationship [19]. The results of data processing indicate that there is a strong relationship between the use of social media and the experiences of respondents. So it can be assumed that the more frequent usage of the media will increase the welfare or happiness of women. The residual value of the calculation is $1-\mathrm{R} 2$ or $(1-0352) \%=64.8 \%$. This figure is large enough to show that many other aspects determine women's happiness when using and utilizing social media as a means to express themselves in the context of online business activities.

\begin{tabular}{|c|c|c|c|c|c|c|c|c|c|}
\hline \multirow{2}{*}{ Model } & \multirow{2}{*}{$\mathrm{R}$} & \multirow{2}{*}{$\begin{array}{c}\mathrm{R} \\
\text { Square }\end{array}$} & Adjusted R & \multirow{2}{*}{$\begin{array}{c}\text { Std. Error } \\
\text { Square } \\
\text { of the } \\
\text { Estimate }\end{array}$} & $\begin{array}{c}\text { R Square } \\
\text { Change }\end{array}$ & $\begin{array}{c}\mathrm{F} \\
\text { Change }\end{array}$ & df1 & df2 & $\begin{array}{c}\text { Sig. F } \\
\text { Change }\end{array}$ \\
\hline 1 & $.605^{\mathrm{a}}$ & .367 & .352 & 1.98984 & .367 & 24.888 & 1 & 43 & .000 \\
\hline
\end{tabular}

Community life makes the achievements of men and women differ in various aspects of life. This disparity in life outcomes is generally because it is still fixated on patriarchal culture so that women are often considered to be the second creature, and are therefore often found to be lagging behind men in the fields of health, education, and economics.

The ease of accessing social media also gives women time flexibility to use it. They can manage the shop, peddle their wares, and make money without leaving home. The domestic role that is often assigned to her, as a mother who takes care of her family, husband and children. It can be harmonized or can be done simultaneously with her desire to develop themselves economically and empowered by opening an online store.

The presence of the internet provides for the improvement of human life, especially in communication technology. In Indonesia, internet penetration is growing rapidly every year. Here it seems that there is almost no difference between the number of women and men who use the internet. They both use the internet in their daily lives. Both men and women use it to get the latest information, interact by utilizing social media and also for other conveniences.

Nevertheless, behind the ease of using social media as marketing media, there are also weaknesses. The APJII Survey [6] notes that in general Indonesian people, without distinguishing between women and men who are exposed to internet media, spend at least 8 (eight) hours a day. Most of the time is used to access social media, watch movies or just listen to the latest music entertainment. Based on this survey, it can be imagined that social media colors people's lives in their daily lives. There is no day without the internet.

For businesswomen, social media can become addictive which ultimately makes their efforts to harmonize with the domestic role can be in chaotic. Although the results of the study stated that women generally have the ability to multitasking, but it cannot be denied that women's attention eventually became divided.

The time that should be of quality to care for and serve the family is ultimately divided as well. Consumer demand often does not aware and consider the time. Consumers belief that they can contact at any time and demand to be served also at any time. This can trigger frustration. Women do not enough time for their self and push her not to ignore, consumers, because it can make people run away and choose to look for other competitors' online stores.

This condition is also compounded by the existence of customer complaints to be immediately addressed. Shopping at online stores cannot be directly felt by buyers. They only 
rely on perception when looking at pictures or photos and will find out their original form after the item has been received. The discrepancy in size, color, and expectations when perceiving has the potential to cause disappointment to consumers. Lately, many online business' people also take advantage of platforms e-commerce that makes it a bit easier for them to handle their online stores. But still, small business entrepreneurs generally do not have workers or assistants. Everything is handled alone so that eventually women experience great stress and lead to unhappiness and cause a decrease in motivation and creativity.

\section{Conclusion}

People do selection while using internet media. Although both are accessing the internet in communicating through the internet media, both men and women still have their unique ways to use it. These differences can be utilized and maximized according to their respective abilities or competencies.

Women use social media for daily small business activities that reflects their creativeness based on their expectations to live happy. Based on the results of this study, it can be obtained that women who use social media as a marketing communication medium of their business tend to have happy experiences. This finding is certainly can contribute to the aspect of improving the quality of life. The maximum use of social media is certainly expected to be able to encourage empowerment and improvement of the quality of Indonesian women's development.

Furthermore, it is very clear that studies like this need to be further developed to elaborate on aspects that can be encouraged and strengthened women's empowerment such as in decision making, involvement and active role in the public sphere in a business or economic context.

\section{References}

[1] F.-J. Richter, Economic Development and Crisis in East Asia, In Frank-Jurgen Richter (Ed.), The East Asia Development Model: Economic Growth, Institutional Failure and The Aftermath of The Crisis. London, UK: Mac Millan Press, 2000.

[2] F. Robins, Asia's 1997 Crash: Its Character, Causes and Consequences, In Frank-Jurgen Richter (Ed.), The East Asia Development Model: Economic Growth, Institutional Failure and The Aftermath of The Crisis,. London, UK: MacMillan Press, 2000.

[3] IWAPI, "IWAPI Berdayakan Perempuan Lewat UKM Jakarta," Message Posted from Suara Merdeka News, Indonesian Business Women's Association, 2012.

[4] F. Taufik, “Article: 14 Juta Usaha di Indonesia Dikelola Wanita,” 2019.

[5] A. Bhatnagar, B. R. Bhardwaj, and S. Gandhi, "Problems and Challenges faced by Women Entrepreneur in India."

[6] Asosiasi Penyedia Jasa Internet Indonesia (APJII), Laporan Survei: Penetrasi dan Profil Pelaku Pengguna Internet Indonesia. 2018.

[7] J. T. Wood, Gendered Lives. Boston: Wadsworth, 2013.

[8] D. Davis and S. J. Baran, Mass Communication Theory: Foundations, Ferment, and Future, 6th ed. Boston: Wadsworth, 2006.

[9] D. Zarella, The Social Media Marketing Book. Jakarta: PT Serambi Ilmu Semesta, 2010.

[10] E. Ardianto, "Komunikasi 2.0 Teoritisasi dan Implikasi," Jakarta: Aspikom, 2011.

[11] J. A. Bargh, K. Y. A. McKenna, and G. M. Fitzsimons, "Can you see the real me? Activation and expression of the 'true self' on the Internet," J. Soc. Issues, vol. 58, no. 1, pp. 33-48, 2002.

[12] R. P. Castillo, "People You may (or May Not): Usage Intensity, Status Motivation, and Intimate Self Disclosure as Predictors of Bridging Sosial Capital on Facebook. The Hilltop Review, Vol 
10, Issue 1: Article 4," 2017.

[13] S. S. Wang, "To Tweet or Not to Tweet: Factors Affecting the Intensity of Twitter Usage in Japan and Online and Offline Sociocultural Norms," Int. J. Commun., vol. 10, pp. 2637. - 2660, 2016.

[14] I. Karyono and Y. Rahayu, Pembangunan Manusia Berbasis Gender. Jakarta: Kerjasama KPPPA dengann BPS, 2018.

[15] C. L. Proctor, "Subjective Well-Being in Greydanus, D.E. Pratt, H.D. \& Patel, D.R. (2013) Health Promotion: Adolescent Well Being In Michalos ,A (Ed). Encyclopedia of Quality of Life and Well-Being Research. Springer, Dordrecht, Netherlands: Springer (pp. 6437-6441)," 2014.

[16] E. Diener, S. Oishi, and R. E. Lucas, Subjective well-being: The science of happiness and life satisfaction in C. R. Snyder \& S. J. Lopez (Eds.), Handbook of positive psychology (pp. 63-73). New York: Oxford University Press, 2002.

[17] E. Diener, S. Oishi, and Suh e, "Recent findings on subjective well-being," Indian J. Clin. Psychol., vol. 24, pp. 25-41, 1997.

[18] N. B. Ellison, C. Steinfield, and C. Lampe, "The Benefits of Facebook 'Friends:' Social Capital and College Students' Use of Online Social Network Sites," J. Comput. Commun., vol. 12, pp. 1143-1168, 2007.

[19] Sugiyono, Metode Penelitian Bisnis. Bandung: Alfabeta, 2007. 